\author{
Anna MATRAS-BOLIBOK ${ }^{1}$ \\ Tomasz KIJEK ${ }^{2}$
}

\title{
FACTORS BEHIND THE INNOVATION PERFORMANCE IN THE EUROPEAN REGIONS
}

\begin{abstract}
Identification of the factors that shape the effectiveness of innovation activities is important for promoting regional development. The paper aims at evaluation of determinants of innovation performance in the European regions. In order to investigate this issue we apply a fixed effects regression model on a 5-year longitudinal dataset of 190 European regions. We explore four groups of determinants of innovation performance: technological innovation capital, non-technological innovation capital, human capital and network capital of regions. In order to assess regional innovation performance we use a variable measuring the relative ability of firms to generate revenues from sales of product or process innovations. The results of analysis indicate that all examined forms of regional innovation capital exert positive and statistically significant impact on innovation performance, except human capital for which our evidence seems ambiguous. The strongest impact on the relative ability to generate revenues from sales of innovations seems to be exerted by the technological innovation capital (measured by intensity of public sector R\&D expenditures), closely followed by non-technological innovation capital (measured by the non-R\&D innovation expenditures in firms). Our results also demonstrate a somewhat weaker, positive influence of collaboration on innovative activities (used as a proxy of network capital) on the aforementioned firms' revenues. Surprisingly, human capital (measured by the share of population aged 25-64 with tertiary education attainment) turned out to have positive but statistically insignificant impact on innovation performance.
\end{abstract}

Keywords: R\&D expenditures, technological capital, non-R\&D expenditures, human capital, network capital, effectiveness.

\footnotetext{
${ }^{1}$ Dr Anna Matras-Bolibok, Katedra Ekonomii i Agrobiznesu, Uniwersytet Przyrodniczy w Lublinie, ul. Akademicka 13, 20-950 Lublin; tel. (81) 461-00-61, int. 28, autor korespondencyjny, e-mail: anna.matras@up.lublin.pl

Anna Matras-Bolibok, Phd, Department of Economics and Agribusiness, University of Life Sciences in Lublin, ul. Akademicka 13, 20-950 Lublin; tel. (81) 461-00-61, int. 28, corresponding author, e-mail: anna.matras@up.lublin.pl

${ }^{2}$ Dr hab. Tomasz Kijek, Katedra Zarządzania Jakością i Wiedzą, Uniwersytet Marii Curie-Skłodowskiej w Lublinie, Plac Marii Curie-Skłodowskiej 5, 20-031 Lublin; e-mail: tomasz.kijek@poczta. umcs.lublin.pl

Tomasz Kijek, DSc, PhD, Department of Quality and Knowledge Management, Maria Curie-Skłodowska University in Lublin, Plac Maria Curie-Skłodowskiej 5, 20-031 Lublin; e-mail: tomasz.kijek@poczta.umcs.lublin.pl
} 


\section{INTRODUCTION}

It is commonly considered that innovation is an inevitable condition for gaining competitive advantage of economies. However, it is worth to point out that only effective innovation processes could contribute to economic development in a long-run. The absence of measurable results in the form of the revenues from implementation of the invention to market or from improvement of production processes could undermine the point of conducted innovation activities. Expectation of serendipity is not relevant strategy for innovation improvement in the contemporary economies, as it should be purposefully directed and supported within the mechanisms of innovation policy. As innovation is a complex process shaped by a large number of mutually interacting determinants, the question arise, which of them are the most important in affecting the innovation performance.

Given the above considerations, the aim of the paper is to determine the factors behind the innovation performance in the European regions. The structure of the paper is as follows. The next successive section is devoted to the background literature on the determinants of innovation performance. In the third section, we provide the details of the research design (data and methodology). The following section presents the main results of analysis. The last section is devoted to main conclusions, including some implications for regional innovation policies.

\section{DETERMINANTS OF INNOVATION PERFORMANCE}

As innovation is a complex process its effectiveness is shaped by a large number of mutually interacting determinants. Innovative performance of firms could be explained both by intra-firm features and the external factors, called knowledge spillovers, that refer to the positive externalities that firms gain from the environment in which they operate ${ }^{3}$.

One of the most important determinants of innovation performance is technological capital, that refers to the intensity of R\&D activities. These activities are usually conducted by research units, universities, or enterprises and financed from public and private sources of funds. As market failures associated with $R \& D$ activities exist, the government support to business R\&D is fully justified. Public support may improve innovative capacity by fostering industrial $\mathrm{R} \& \mathrm{D}$, funding academic research, and supporting university-industry collaboration to strengthen the linkage between R\&D and product development. The major policy tools used by the governments to support business R\&D include grants, procurement, tax incentives and direct performance of research ${ }^{4}$. What is worth to point out the empirical analyses also revealed that public financial support is complementary to private R\&D expenditures and innovative productivity in the EU regions ${ }^{5}$. X. Sun, H. Li, and V. Ghosal found that $R \& D$ expenditures appear to have a more potent effect on innovation in the less

\footnotetext{
${ }^{3}$ R. Capello, A. Faggian, Collective Learning and Relational Capital in Local Innovation Processes, Regional Studies, Vol. 39, Issue 1, 2005, p. 75-87.

${ }^{4} \mathrm{M}$. Savrula, A. Incekara, The Effect of R\&D Intensity on Innovation Performance: A Country Level Evaluation Procedia - Social and Behavioral Sciences 210, 2015, p. 388-396.

5 T. Kijek, A. Matras-Bolibok, E. Rycaj, Do Public R\&D Expenditures Foster Business R\&D Investments? "International Journal of Synergy and Research", Vol. 5, 2016, p. 147-154.
} 
developed areas within the country, suggesting that policies promoting R\&D should focus on the less developed regions for greater nationwide effectiveness and innovation increase ${ }^{6}$.

Although R\&D provides many advantages, it does not create economic benefits per se, but in order to achieve this goal R\&D must lead to innovation and to the diffusion of productivity-enhancing technologies ${ }^{7}$. So, it could be stated that another determinant of innovation performance is non-R\&D innovation capital, that refers to several components of innovation activities, such as investment in machinery and equipment or the acquisition of patents and licenses. It is often an important composition of firm innovation, especially in developing countries ${ }^{8}$. As C. Huang, A. Arundel, and H. Hollanders revealed, firms in low-tech manufacturing sectors and firms based in catching up countries increase the share of their innovation expenditures for non-R\&D activities as their innovation intensity increases ${ }^{9}$. Moreover, non R\&D activities are distinctly important for innovation performance in regions, as research showed that about half of European firms which report introduction of product or process innovations do not perform R\&D in-house ${ }^{10}$.

The capacity to innovate is also viewed to be a function of a region's ability to attract human capital and to provide low barriers to entry for talented and creative people of all backgrounds ${ }^{11}$. Human capital, being complementary to technological capital, is commonly considered to be a stimulus of innovation processes. N.G. Mankiw, D. Romer, and D.N. Weil, introduced human capital to growth model assuming that it determines technological progress $^{12}$, while P. Romer emphasized that innovation is produced by combining R\&D and human capital together ${ }^{13}$. The endogenous growth theory considers human capital as one of the most important inputs in innovation from the macro level perspective. This macro approach gives the clues to emphasize the importance of human capital in micro level and its role in improving the innovation capacity of firms. According to R.R. Nelson and E.S. Phelps human capital not only determines the ability to create innovation, but also contributes to diminish the technological gap between more and less developed economies through imitation and absorption of innovation ${ }^{14}$.

The link and liaison between the human and technological capital is the network capi$\operatorname{tal}^{15}$. It is assumed that acquisition of knowledge by firms depends not only on the market

${ }^{6}$ Sun X., Li H., Ghosal V., Firm-Level Human Capital and Innovation: Evidence from China, CESifo Working Paper Series No. 6370, 2017.

7 C. Huang, A. Arundel, H. Hollanders, How firms innovate: $R \& D$, non-R\&D, and technology adoption, UNU-MERIT Working Papers No. 027 ISSN 1871-9872, 2010.

8 Sun X., Li H., Ghosal V., op. cit.

9 C. Huang, A. Arundel, H. Hollanders, op. cit.

${ }^{10}$ Ibidem.

${ }^{11}$ S.Y. Lee, R. Florida, G. Gates, Innovation, Human Capital, and Creativity, "International Review of Public Administration", Vol. 14, Issue 3, 2010, p. 13-24.

12 N.G. Mankiw, D. Romer, D.N. Weil, A Contribution to the Empirics of Economic Growth, "The Quarterly Journal of Economics", Vol. 107, No. 2, 1992, p. 405-437.

${ }^{13}$ P. Romer, Endogenous Technological Change, "Journal of Political Economy", Vol. 98, no. 5, 1990, p. 71-102.

${ }^{14}$ R.R. Nelson, E.S. Phelps, Investment in humans, technological diffusion, and economic growth, "The American Economic Review", Vol. 56, No. 1/2, 1966, p. 69-75.

15 A. Badiola, P. Casares-Hontañón, P. Coto-Millán, M. Ángel Pesquera, Networks and Innovation: An Economic Model for European Regions (2002-2006), "Journal of Knowledge Management, Economics and Information Technology", Vol. 2, Issue 5, 2012, p. 44-55. 
or the hierarchy but also on the social capital accumulated within regions through networks of interactions and learning ${ }^{16}$. Collaborative relationships that exist between actors of the innovation process (universities, private companies, and public administration) are really relevant and necessary to implement inventions to the market. The universities and $\mathrm{R} \& \mathrm{D}$ units provide a foundation of scientifically-trained human capital, that adequately related to private enterprise can generate open innovation ${ }^{17}$. Network capital is considered to be an important determinant of innovation performance as collaboration on innovation activities with other firms or institutions creates opportunities to access complementary knowledge or technological resources which can contribute to faster development of innovations and should lead to the increase of their effectiveness. It is particularly important for small and medium-sized firms which might improve their innovative performance and obtain the advantages typical for large enterprises through participation in networks of collaboration ${ }^{18}$.

As it is commonly acknowledged, collaboration is associated with geographical proximity and the main space of innovation processes and collaboration on innovative activity is region ${ }^{19}$. It can be assumed that knowledge spillovers, concentrated in spatial proximity to their respective source, constitute an important factor in shaping the regional conditions for innovation activities ${ }^{20}$. However, as Boschma points out, geographical proximity per se is neither necessary nor sufficient condition for interactive learning to take place $^{21}$. Also other kinds of proximities, like relational, social, and technological proximity, play important role in explaining effectiveness ${ }^{22}$.

Contextual elements connected with regional environment and the presence of systemic interactions in the process of generation and diffusion of innovation appear to be important determinants of innovation performance in regions. However, according to I. De Noni, A. Ganzaroli, and L. Orsi, local collaboration has a curvilinear effect on the knowledge productivity of regions and that there is an optimal level of intra-regional collaboration and that inter-regional collaborations positively affect the innovation performance of regions only if balanced with intra-regional collaboration ${ }^{23}$. Moreover, collaboration, especially

${ }^{16}$ R. Landry, N. Amara, M. Lamari, Does social capital determine innovation? To what extent? "Technological Forecasting and Social Change", Vol. 69, Issue 7, 2002, p. 681-701.

17 A. Badiola, P. Casares-Hontañón, P. Coto-Millán, M. Ángel Pesquera, op. cit.

18 A. Matras-Bolibok, Does firm's size impact innovative performance?, "International Journal of Innovation and Learning”, Vol. 4, No 15, 2014, p. 422-431.

${ }^{19}$ M.P. Feldman, R. Florida, The Geographic Sources of Innovation: Technological Infrastructure and Product Innovation in the United States, "Annals of the Association of American Geographers", Vol. 84, No 2, 1994, p. 210-229.

20 M. Fritsch, G. Franke, Innovation, regional knowledge spillovers and R\&D cooperation, "Research Policy", Vol. 33, 2004, p. 245-255.

${ }^{21}$ R. Boschma, Proximity and Innovation: A Critical Assessment, "Regional Studies", Vol. 39, Issue. 1, 2005, p. 61-74.

${ }^{22}$ R. Basile, R. Capello, A. Caragliu, Technological interdependence and regional growth in Europe: proximity and synergy in knowledge spillovers, "Papers in Regional Science", Vol. 91, 2012, p. 697-722.

23 I. De Noni, A. Ganzaroli, L. Orsi, The impact of intra- and inter-regional knowledge collaboration and technological variety on the knowledge productivity of European regions, "Technological Forecasting and Social Change", Vol. 117, 2017, p. 108-118. 
with highly innovative regions, positively affects the innovation performance of laggingbehind regions ${ }^{24}$.

\section{RESEARCH DESIGN}

In the economic literature innovation performance of European regions is usually measured by the EPO patent applications. This indicator, however does not reveal measureable financial effects of innovation activity and advantages for the region. Thus, in our study we employ revenues from sales of innovations in firms as a variable that should capture the financial effects of innovation activity.

All prior presented arguments have led us to put forward the following research hypothesis:

H1: Regional innovation performance, measured by the revenues from sales of innovations is determined by mutually reinforced technological innovation, non-technological innovation, as well as human and network capital of a region.

The research was based on the data extracted from the Regional Innovation Scoreboards (RIS) of the European Union, that provides a comparative assessment of innovation performance at the regional level of the EU Member States and other European countries (Norway and Switzerland). In order to ensure a possibly most complete and balanced dataset we examined the data for the 190 European regions over 5 years: 2007, 2009, 2011, 2014, and 2016. Under the RIS methodology ${ }^{25}$ the data on particular statistical indicators are normalised by using the min-max scaling technique (equation 1). The normalised value for a given region equals the difference between its actual value and the lowest value across all regions divided by the difference between the highest and lowest value across all regions, thus yielding a number between 0 and 1 . Additionally, if the normalised data significantly deviate from normal distribution, they are further transformed using a power root transformation.

$$
z_{i t}=\frac{x_{i t}-x_{t \min }}{x_{t \max }-x_{t \min }}
$$

where: $z_{i t}$ - normalised value of variable $x$ in region $i$ in the year $t$,

$x_{i t}-$ actual value of variable $x$ in region $i$ in the year $t$,

$x_{t \text { min }}-$ minimum value of variable $x$ in all regions in the year $t$,

$x_{t \min }-$ maximum value of variable $x$ in all regions in the year $t$.

Due to the fact that the analysed sample is likely to be characterized with individual heterogeneity we apply panel data regression modelling. In order to test the formulated hypothesis we choose a measure of relative ability to generate revenues from sales of innovations as a dependent variable. As explanatory variables we employ indicators representing each form of regional innovation capital, i.e. technological innovation capital - measured

${ }^{24}$ I. De Noni, L. Orsi, F. Belussi, The role of collaborative networks in supporting the innovation performances of lagging-behind European regions, "Research Policy", Vol. 47, Issue 1, 2018, p. 1-13.

25 H. Hollanders, N. Es-Sadki, M. Kanerva, Regional Innovation Scoreboard 2016. Methodology report, European Commission, Ref. Ares(2016)3414626 - 14/07/2016. 
by public R\&D expenditures, non-technological innovation capital - measured by nonR\&D innovation expenditures in firms, network capital - measured by the share of enterprises collaborating on innovation activity, and human capital - measured by the share of population aged 25-64 with tertiary education attainment. Moreover, we introduce two control variables: GDP per capita (as a proxy of a region's overall wealth, which reflects the availability of financial resources to support regional development, including R\&D investments) and the share of enterprises that introduced product or process innovations.

Given the above, the following fixed effects panel regression model was constructed (equation 2):

$$
\begin{aligned}
\text { Sales }_{\text {of }_{\text {innov }} \text { it }}= & \beta_{0}+\beta_{1} \cdot P u b_{-} R \& D_{-} \exp _{i t}+\beta_{2} \cdot N o n_{-} R \& D_{-} i n n o v_{-} \exp _{i t} \\
& +\beta_{3} \cdot \text { Pop }_{\text {with }_{\text {tertriary }} \text { edu }}+\beta_{4} \cdot \text { Innov_SMES_coll }_{i t} \\
& +\beta_{5} \cdot S M E S_{-} \text {intro_innov }_{i t}+\beta_{6} \cdot G D P_{p c}+\varepsilon_{i t}
\end{aligned}
$$

where: Sales_of_innov ${ }_{i t}$ - sales of new-to-market and new-to-firm innovations in SMEs in region $i$ in the year $t$,

$\beta_{0}, \beta_{1}, \ldots, \beta_{6}$ - regression parameters,

$P u b \_R \& D \_\exp _{i t}-$ public R\&D expenditures (in the government sector and the higher education sector) in region $i$ in the year $t$,

$N o n_{-} R \& D \_i n n o v \_\exp _{i t}-$ non-R\&D innovation expenditures in the SME sector in region $i$ in the year $t$,

Pop_tertriary_edu $u_{i t}$ - share of population aged 25-64 with tertiary education attainment in region $i$ in the year $t$,

Innov_SMES_coll ${ }_{i t}$ - share of SMEs collaborating on innovation activity in region $i$ in the year $t$,

SMEs_intro_innov $v_{i t}$ - share of SMEs that introduced product or process innovations in region $i$ in the year $t$,

$G D P \_p c_{i t}-$ gross domestic product per person in region $i$ in the year $t$,

$i=1,2, \ldots, 190$ - region's numeric identifier in the examined sample,

$t=2007,2009,2011,2014,2016-$ year of observation.

\section{EMPIRICAL RESULTS}

The results of the F-test for the equality of unique errors across the examined regions indicate the presence of individual heterogeneity which justifies the use of panel data regression methods. In order to determine the appropriate estimation technique (fixed vs. random effects) we employed the Hausman specification test ${ }^{26}$. The results of Hausman test indicate that the model's unique errors are statistically significantly correlated with the selected regressors, which supports the use of fixed effects instead of random effects model.

Following the results of the modified Wald test for the presence of groupwise heteroscedasticity in the model we estimate robust (Huber/White) standard errors.

The results of the model estimation are presented in Table 1.

\footnotetext{
${ }^{26}$ W.H. Greene, Econometric analysis. 6th ed., Prentice Upper Saddle River, N.J. Hall, 2008.
} 
Table 1. Results of the fixed effects regression model estimation

\begin{tabular}{|c|c|c|c|c|c|c|}
\hline \multirow[t]{2}{*}{ Variable } & \multirow[t]{2}{*}{$\begin{array}{l}\text { Coefficient } \\
\text { estimate }\end{array}$} & \multirow{2}{*}{$\begin{array}{c}\text { Robust } \\
\text { standard } \\
\text { error }\end{array}$} & \multirow[t]{2}{*}{$\begin{array}{c}\text { t-statis- } \\
\text { tic }\end{array}$} & \multirow[t]{2}{*}{$P$-value } & \multicolumn{2}{|c|}{$\begin{array}{c}95 \% \text { confidence } \\
\text { interval }\end{array}$} \\
\hline & & & & & $\begin{array}{l}\text { Lower } \\
\text { bound }\end{array}$ & $\begin{array}{l}\text { Upper } \\
\text { bound }\end{array}$ \\
\hline Pub_R\&D_exp & 0.241 & 0.066 & 3.65 & 0.000 & 0.111 & 0.371 \\
\hline Non-R\&D inn exp & 0.228 & 0.041 & 5.52 & 0.000 & 0.146 & 0.309 \\
\hline Pop_tertiary_edu & 0.096 & 0.134 & 0.71 & 0.476 & -0.168 & 0.360 \\
\hline Inn_SME_coll_ & 0.168 & 0.058 & 2.88 & 0.004 & 0.053 & 0.283 \\
\hline SMEs_intro_inn & 0.292 & 0.056 & 5.25 & 0.000 & 0.182 & 0.401 \\
\hline GDP per capita & 0.804 & 0.170 & 4,73 & 0.000 & 0.468 & 1.139 \\
\hline Intercept & -0.228 & 0.084 & -2.71 & 0.007 & -0.395 & -0.062 \\
\hline F-statistic & 39.77 & & & 0.000 & & \\
\hline Rho (fraction of variance due & 0.758 & & & & & \\
\hline $\begin{array}{l}\text { to differences across regions) } \\
\mathrm{R}^{2 .}\end{array}$ & & & & & & \\
\hline & & & & & & \\
\hline - within regions & 0.2684 & & & & & \\
\hline - between regions & 0.3001 & & & & & \\
\hline - overall & 0.2277 & & & & & \\
\hline Number of observations & 950 & & & & & \\
\hline Number of regions & 190 & & & & & \\
\hline
\end{tabular}

Source: own compilation

As expected, all identified descriptors were found to be positively correlated with the dependent variable. Except for the share of population aged 25-64 with tertiary education attainment, all estimated regression coefficients turned out to be statistically significant at the $5 \%$ level.

The strongest impact on the SMEs' relative ability to generate revenues from sales of innovative products and processes seems to be exerted by the intensity of public sector $R \& D$ expenditures, closely followed by non-R\&D innovation expenditures. Our results also demonstrate a somewhat weaker, yet still statistically significant, positive influence of collaboration on innovative activities on the aforementioned SMEs' revenues.

Surprisingly, the regression coefficient for the share of population aged 25-64 with tertiary education attainment turned out to be insignificantly different from zero. This unexpected finding suggest that despite the fact that better educated population should stimulate and facilitate innovation processes, at the same time it might represent more demanding and harder-to-satisfy customers. Another possible explanation might be more intense competition that is likely to occur in the regions with better-educated population.

\section{CONCLUSIONS}

The results of the research seem to support the key hypothesis of the present study. In general, regions characterised with higher level of technological innovation, non-technological innovation and network capital tend to demonstrate higher effectiveness of innovative activities, as measured by the revenues from sales of innovative products. These results confirm an important role of public financial support for innovation activities. Additionally, bearing in mind demonstrated relatively high impact of non-R\&D expenditures in the EU 
firms and the fact that more than a half of EU enterprises introducing innovation to market does not conduct R\&D activities, public financial support should also be directed to nontechnological innovation in firms. A revealed positive impact of collaboration on effectiveness of innovation activities may also give the clues to emphasize the importance of creation favourable conditions for the interactions between innovation-active entities in the regions. In this field important role could be assigned to appropriate mechanisms and instruments of regional and innovation policies, which should facilitate the emergence of the networks of collaboration.

\section{REFERENCES}

1. Badiola A., Casares-Hontañón P., Coto-Millán P., Ángel Pesquera M., Networks and Innovation: An Economic Model for European Regions (2002-2006), "Journal of Knowledge Management, Economics and Information Technology", Vol. 2, Issue 5, 2012.

2. Basile R., Capello R., Caragliu A., Technological interdependence and regional growth in Europe: proximity and synergy in knowledge spillovers, "Papers in Regional Science", Vol. 91, 2012.

3. Boschma R., Proximity and Innovation: A Critical Assessment, "Regional Studies", Vol. 39, Issue. 1, 2005.

4. Capello R., Faggian A., Collective Learning and Relational Capital in Local Innovation Processes, "Regional Studies", Vol. 39, Issue 1, 2005.

5. De Noni I., Ganzaroli A., Orsi L., The impact of intra- and inter-regional knowledge collaboration and technological variety on the knowledge productivity of European regions, "Technological Forecasting and Social Change", Vol. 117, 2017.

6. De Noni I., Orsi L., Belussi F., The role of collaborative networks in supporting the innovation performances of lagging-behind European regions, "Research Policy", Vol. 47, Issue $1,2018$.

7. Feldman M.P., Florida R., The Geographic Sources of Innovation: Technological Infrastructure and Product Innovation in the United States, "Annals of the Association of American Geographers", Vol. 84, No 2, 1994.

8. Fritsch M., Franke G., Innovation, regional knowledge spillovers and R\&D cooperation, "Research Policy", Vol. 33, 2004.

9. Greene W.H., Econometric analysis. 6th ed., Prentice Upper Saddle River, N.J. Hall, 2008.

10. Hollanders H., Es-Sadki N., Kanerva M., Regional Innovation Scoreboard 2016. Methodology report, European Commission, Ref. Ares(2016)3414626 - 14/07/2016.

11. Huang C., Arundel A., Hollanders H., How firms innovate: $R \& D$, non-R\&D, and technology adoption, UNU-MERIT Working Papers No. 027 ISSN 1871-9872, 2010.

12. Kijek T., Matras-Bolibok A., Rycaj E., Do Public R\&D Expenditures Foster Business $R \& D$ Investments? "International Journal of Synergy and Research", Vol. 5, 2016.

13. Landry R., Amara N., Lamari M., Does social capital determine innovation? To what extent? "Technological Forecasting and Social Change", Vol. 69, Issue 7, 2002.

14. Lee S.Y., Florida R., Gates G., Innovation, Human Capital, and Creativity, "International Review of Public Administration”, Vol. 14, Issue 3, 2010.

15. Mankiw N.G., Romer D., Weil D.N., A Contribution to the Empirics of Economic Growth, "The Quarterly Journal of Economics", Vol. 107, No. 2, 1992. 
16. Matras-Bolibok A., Does firm's size impact innovative performance?, "International Journal of Innovation and Learning", Vol. 4, No 15, 2014.

17. Nelson R.R., Phelps E.S., Investment in humans, technological diffusion, and economic growth, "The American Economic Review", Vol. 56, No. 1/2, 1966.

18. Romer P., Endogenous Technological Change, "Journal of Political Economy", Vol. 98, No. 5, 1990.

19. Savrula M., Incekara A., The Effect of R\&D Intensity on Innovation Performance: A Country Level Evaluation Procedia - Social and Behavioral Sciences 210, 2015.

20. Sun X., Li H., Ghosal V., Firm-Level Human Capital and Innovation: Evidence from China, CESifo Working Paper Series No. 6370, 2017.

\title{
CZYNNIKI DETERMUNUJĄCE EFEKTYWNOŚĆ DZIAŁALNOŚCI INNOWACYJNEJ W EUROPEJSKICH REGIONACH
}

\begin{abstract}
Identyfikacja czynników kształtujących efektywność działalności innowacyjnej jest istotna dla wyznaczania kierunków wsparcia rozwoju regionalnego. Celem artykułu jest określenie determinant efektywności działalności innowacyjnej w europejskich regionach. Do analizy wytyczonego problemu badawczego wykorzystano model regresji panelowej z efektami stałymi, bazując na danych panelowych dla 190 europejskich regionów dla 5 wybranych lat z okresu 2007-2016. Analizie poddano cztery grupy czynników determinujących efektywność działalności innowacyjnej: technologiczny kapitał innowacyjny, nietechnologiczny kapitał innowacyjny, kapitał ludzki oraz kapitał sieci w regionach. Jako miarę efektywności działalności innowacyjnej przyjęto zmienną określającą relatywną zdolność do osiągania przez przedsiębiorstwa przychodów ze sprzedaży innowacji produktowych lub procesowych. Przeprowadzone analizy wykazały, że wszystkie badane grupy kapitału innowacyjnego regionu wykazały pozytywny i statystycznie istotny wpływ na efektywność działalności innowacyjnej, poza kapitałem ludzkim, którego wpływ okazał się być niejednoznaczny. Najsilniejszy wpływ na relatywną zdolność do generowania przychodów z innowacji przez przedsiębiorstwa wywierał technologiczny kapitał innowacyjny (mierzony wskaźnikiem intensywności publicznych nakładów na $\mathrm{B}+\mathrm{R}$ ), zaś niemal równie silny wpływ odnotował nietechnologiczny kapitał innowacyjny (mierzony nakładami na działalność innowacyjną $\mathrm{z}$ wyłączeniem nakładów na $\mathrm{B}+\mathrm{R}$ w przedsiębiorstwach). Badania wykazały również pozytywne i statystycznie istotne, chociaż trochę słabsze oddziaływanie współpracy w zakresie działalności innowacyjnej (określającej kapitał sieci) na wskazane przychody. Nieoczekiwanie, kapitał ludzki (mierzony jako udział osób w wieku 25-64 lat z wykształceniem wyższym w całej populacji) okazał się być determinantą pozytywną, ale nieistotną statystycznie.
\end{abstract}

Słowa kluczowe: nakłady na $B+R$, kapitał technologiczny, nakłady na innowacje poza $B+R$, kapitał ludzki, kapitał sieci, efektywność.

DOI: 10.7862/rz.2018.hss.27

Przestano do redakcji: luty $2018 \mathrm{r}$. Przyjęto do druku: czerwiec 2018 r. 
